\title{
Estimation of pollution load from an industrial estate, south-western Nigeria
}

\author{
Effiong Ukorebi ETIM
}

\begin{abstract}
Department of Chemistry, University of Ibadan, Ibadan, Nigeria. E-mail: etim242@yahoo.com. Tel: +234-08033690012.
Accepted 19 January, 2012

The Ota industrial estate being one of the largest in the southwestern Nigerian, contributes significantly to its socio-economic development. This study is design to generate the much needed industrial emission data for efficient environmental monitoring and compliance. The industrial pollution projection survey (IPPS) and rapid pollution inventory survey (RPIS) models developed by the World Bank were used for the estimation of pollution loads. The results showed that a total of 6970 tons/yr of air pollutants $\left(\mathrm{SO}_{2}, \mathrm{NO}_{2}, \mathrm{CO}, \mathrm{VOC}\right.$ and $\left.\mathrm{PM}\right), 10800$ tons/yr of wastewater pollutants (BOD and TSS) and 1090 tons/yr of toxic pollution (air, land and water) were released into the environment from the industrial estate. Carbon monoxide accounted for the highest air pollution load representing $57.5 \%$. About $64.0 \%$ of the total pollution load of the industrial estate was contributed by industries in the basic metal, iron, steel and fabricated metal works sector. There is need for industrial emission monitoring and enforcement for pollution control and abatement. Similarly, efficient and environmentally friendly waste management practices should be adopted within the confines of this all-important industrial estate.
\end{abstract}

Key words: Industrial pollution projection survey (IPPS), rapid pollution inventory survey (RPIS), models, industrial estate, industrial emission, carbon monoxide.

\section{INTRODUCTION}

Industrial pollution is fast becoming a major problem in many developing countries. The extensiveness of these problems is colossal to the economies. This is attributed to the absence of reliable and comprehensive system of monitoring of environmental data on industrial emissions, and secondly to inadequate resources. The enforcement of compliance on industrial emissions with relevant regulatory standards is therefore seen as ineffective. Recent advances, are been channelled on cheaper and reliable ways of generating environmental data on industrial emissions. Models are now gaining wide applications in this area (Chou-Ping et al., 2010). Although various models are currently in use, the industrial pollution projection survey (IPPS) model developed by the World Bank (Hettige et al., 1995) has gain considerably wide application. IPPS operates through sector estimates of pollution intensity (usually defined as pollution per unit of output and pollution per unit of employment). It exploits the fact that industrial pollution is heavily affected by the scale of industrial activity, technological application and its sectoral composition. Results from IPPS model have been used in various developing countries where insufficient data on industrial pollution proved to be an impediment to setting up pollution control strategies and prioritization of activities. IPPS have been successfully applied for industrial pollution studies in the five largest economies of the western hemisphere (Kenneth and Roland-Holst, 2001; Tsigas et al., 2001), United Kingdom (Smith and Espinosa, 1996), Mexico (Beghin et al., 1995), Indonesia and Japan (Strutt and Kym, 2000; Lee and Roland-Holst, 1997), Uruguay (Ferrantino and Linkins, 1999), Vietnam (World Bank, 1996), Latvia (World Bank, 1993) and Ivory Coast in Africa (Economopoulos, 1979).

Nigeria, being the most populous nation in Africa is witnessing rapid industrial development mostly along its coastal cities. Ogun state is one of such industrialized states in the southwest Nigeria with Ota as its largest industrial city. Ota, the major and central town of Ado Ota Local Government of Ogun State (latitude $6^{\circ} 32^{\prime} \mathrm{N}$, longitude $2^{\circ} 57^{\prime} \mathrm{E}$ ) is a complex setting consisting of many industrial facilities, one of which is the Ota 
Table 1. Classifications of industries.

\begin{tabular}{cllc}
\hline ISIC & Classification & Sector codes & Number of industries \\
\hline 3121 & Food, beverage and tobacco & FBT & 2 \\
3819 & Basic metal, iron, steel and fabricated metal works & BMISFMW & 11 \\
3529 & Chemical and paint & CP & 4 \\
3823 & Wood processing and printing & WPP & 5 \\
3513 & Domestic and industrial plastics & DIP & 4 \\
3829 & Vehicles and mechanical works & VMW & 1 \\
\hline
\end{tabular}

industrial/housing estate. The estate covers approximately $22.8 \mathrm{~km}^{2}$ of land mass. There are different industrial processing plants such as chemical, pharmaceutical, plastics, paper and printing, and metal and steel industries located in close proximity to residential buildings. There are thirty nine industrial sites within the estate, twenty seven of which are currently active while twelve are dormant. The nature of raw materials used by these industries poses great hazard to human health and the environment. Emissions from stacks, effluent discharge and open burning of solid waste are common practices within the estate, and considered environmentally unfriendly. Also the presence of industrial facilities in close proximity to residential houses and the lack of effective environmental data on industrial pollution monitoring give cause for concern. This lack of information makes difficult the identification of priorities of actions, and the implementation of costeffective intervention. The study therefore aims at generating reliable and comprehensive environmental data on the different industrial pollutants generated within the confines of the estate using IPPS model. The results of the IPPS model will be compared with data for the RIPS model to establish any form of relationship.

\section{MATERIALS AND METHODS}

\section{Data collection and inventory}

Data for the estimation of pollution loads contributed by each of the 27 active industries were obtained from the companies' employees and management, and the Ogun State Ministry of Environment through personal meetings and questionnaires (World Bank, 1996). These data included; name of industry, number of employee, raw materials, products and annual production output. From these data, the various industries were classified into six sectoral groups according to the international standard industrial classification (ISIC) system (Table 1).

\section{Pollution load estimation by modeling}

The IPPS and RPIS models developed by the World Bank (Hettige et al., 1995; Economopoulos, 1979) were used to estimate total industrial air pollution load, wastewater pollution load, toxic and toxic metal pollution load from the Ota industrial/housing estate. Each classification contains a set of conventional pollution parameters. The total air pollution load contains; sulphur dioxide
$\left(\mathrm{SO}_{2}\right)$, nitrogen dioxide $\left(\mathrm{NO}_{2}\right)$, carbon monoxide $(\mathrm{CO})$, volatile organic carbon (VOC) and particulate matter (PM). Industrial wastewater pollution loads contains; biochemical oxygen demand (BOD) and total suspended solids (TSS). Industrial toxic and toxic metal pollution loads relates to air, land and water components.

The IPPS modeling system operates through sector estimates of pollution intensity per unit of employment. Employment data from industries were combined with data on the lower bound pollution intensity coefficient to calculate pollution loads in tons/yr as given in the equation.

Pollution loads (tons $/ \mathrm{yr})=\mathrm{P}_{\mathrm{c}} \times \mathrm{N} / \mathrm{C}_{\mathrm{r}}$ (1)

Where $P_{c}$ is pollution intensity coefficient per parameter (pounds/1000 employees per year), $\mathrm{N}$ is the number of employees and $\mathrm{Cr}$ is the conversion factor of pound to tons (2204.6).

In RPIS modeling system, pollution waste factor of all the major polluting industrial activities were multiplied with each corresponding production output to give the pollution loads in tons/yr.

\section{RESULTS AND DISCUSSION}

\section{Industrial air pollution load estimation}

Industrial air emissions consist of various environmentally unfriendly pollutants released into the atmosphere during primary and secondary production processes. Table 2 shows estimated total industrial air pollution load using IPPS model. The total air pollution load of the industrial estate was estimated at 6966.87 tons per year. Carbon monoxide accounted for the highest load of 4008.20 tons/yr representing $57.5 \%$ of the total load. The total emission load estimate of $\mathrm{SO}_{2}(19.6 \%), \mathrm{NO}_{2}(12.7 \%)$ and VOC $(10.2 \%)$ were very similar. Total particulate matter emission was insignificant representing only $0.05 \%$ of the total air emissions load of the estate. The Basic metal, iron, steel and fabricated metal works (BMISFMW) and Chemical and paint (CP) sectoral groups emit the highest amount of the total air pollution load of the estate. The scale of industrial activities and employment strength of these two sectors explains these high emissions load. The Domestic and industrial plastics (DIP) sector is by the nature of its raw material (chemical-based) the third largest generator of air pollutants within the estate, but the fourth in terms of employment strength. The Wood processing and printing (WPP) sector does not generate much air pollutants due largely to the nature of its 
Table 2. Estimated total industrial air pollution loads using IPPS model.

\begin{tabular}{|c|c|c|c|c|c|c|c|c|c|c|c|c|c|c|c|c|}
\hline $\begin{array}{l}\text { Sector } \\
\text { code }\end{array}$ & \multicolumn{2}{|c|}{$\begin{array}{c}\text { No. of } \\
\text { industries }\end{array}$} & \multicolumn{2}{|c|}{$\begin{array}{c}\begin{array}{c}\text { No. of } \\
\text { employee }\end{array} \\
\end{array}$} & \multicolumn{2}{|c|}{$\mathrm{SO}_{2}$} & \multicolumn{2}{|c|}{$\mathrm{NO}_{2}$} & \multicolumn{2}{|c|}{$\mathrm{CO}$} & \multicolumn{2}{|c|}{ VOC } & \multicolumn{2}{|c|}{ PM } & \multicolumn{2}{|c|}{ Total } \\
\hline FBT & 2 & 7.4 & 83 & 2.6 & 3.57 & 0.3 & 3.63 & 0.4 & 0.77 & $<0.01$ & 1.09 & 0.2 & 0.00 & & 9.06 & 0.13 \\
\hline BMISFMW & 11 & 40.7 & 1716 & 52.8 & 976 & 71.5 & 437.98 & 49.7 & 1600.86 & 39.9 & 206.85 & 29.2 & 2.67 & 81.4 & 3224.36 & 46.3 \\
\hline WPP & 5 & 18.5 & 474 & 14.6 & 0.62 & $<0.01$ & 0.44 & $<0.01$ & 9.22 & $<0.01$ & 14.12 & 1.99 & - & - & 24.40 & 0.3 \\
\hline DIP & 4 & 14.8 & 222 & 6.8 & 137.7 & 10 & 357.9 & 40.6 & 52.96 & 1.3 & 262 & 37 & 0.00 & - & 810.56 & 11.6 \\
\hline VMW & 1 & 3.7 & 8 & 0.2 & 0.18 & $<0.01$ & 0.07 & $<0.01$ & 0.15 & $<0.01$ & 0.22 & $<0.01$ & 0.00 & - & 0.62 & $<0.01$ \\
\hline
\end{tabular}

Table 3. Comparison of IPPS and RPIS results (tons/yr) for calculated total air pollution loads.

\begin{tabular}{lcccc}
\hline \multirow{2}{*}{ Parameter } & \multicolumn{2}{c}{ BMISFMW } & \multicolumn{2}{c}{ DIP } \\
\cline { 2 - 5 } & IPPS & RPIS & IPPS & RPIS \\
\hline $\mathrm{SO}_{2}$ & 970.61 & 658.56 & 46.5 & 0.00 \\
$\mathrm{NO}_{2}$ & 287.26 & 900.66 & 120.9 & 0.00 \\
$\mathrm{CO}$ & 1539.0 & 247.5 & 17.86 & 0.00 \\
VOCs & 154.74 & 57.08 & 88.5 & 1.40 \\
$\mathrm{PM}$ & 2.67 & 2390.2 & 0.00 & 11.85 \\
Total & 2954.28 & 4254 & 273.76 & 13.25 \\
\hline
\end{tabular}

processing technology. It has the third largest work force and contributes about the least total air pollution load of the estate. The BMISFMW sector recorded the highest load of $\mathrm{SO}_{2}, \mathrm{NO}_{2}$ and $\mathrm{PM}$ while CP sector generated the highest load of $\mathrm{CO}$. Comparison of IPPS and RPIS results for total air pollution load is showed in Table 3. In BMISFMW sector, IPPS estimated 2954.28 tons/yr and RPIS estimated 4254 tons/yr of total air pollution load. The differential for these sectors was $18.0 \%$ which is incomparable to the $90.8 \%$ for the DIP sector in which IPPS recorded a total of 273.76 tons/yr as against 13.25 tons/yr load for RPIS. The RPIS model estimated a higher PM load than IPPS, but had values of $\mathrm{SO}_{2}, \mathrm{CO}$ and VOC lower than IPPS for the BMISFMW sector. The RPIS model estimation for DIP sector had all five pollutants lower than IPPS. Parametric t-test at 95\% confidence limit showed no significant difference in total air pollution load for the BMISFMW sector, while the DIP sector showed significant difference. Generally, these pollutants are major respiratory disease initiators in humans. The synergetic effects of these pollutants will be very complex in symptoms which could range from brain damage, respiratory disorder, headache, birth defect, fatigue and even death (Ferrantino and Linkins, 1999). $\mathrm{SO}_{2}$ and $\mathrm{NO}_{2}$ are known precursor of acid rain, $\mathrm{NO}_{2}$ suppresses plant growth and damages leaf tissues, while particulates reduce visibility.

\section{Industrial wastewater pollution load}

Table 4 shows estimated total wastewater pollution loads using IPPS model. The total 
Table 4. Estimated total industrial wastewater pollution loads using IPPS model.

\begin{tabular}{lcc|cc|cc|cc|cc}
\hline \multirow{2}{*}{ Sector code } & \multicolumn{2}{c|}{ No. of industries } & \multicolumn{2}{c|}{ No. of employee } & \multicolumn{2}{c|}{ BOD } & \multicolumn{2}{c|}{ TSS } & \multicolumn{2}{c}{ Total } \\
\cline { 2 - 11 } & No. & $\%$ & No. & $\%$ & Tons/yr & $\%$ & Tons/yr & $\%$ & Tons/yr & $\%$ \\
\hline FBT & 2 & 7.4 & 83 & 2.6 & 0.02 & 0.2 & 0.01 & $<0.01$ & 0.03 & $<0.01$ \\
BMISFMW & 11 & 40.7 & 1716 & 52.8 & 2.06 & 25.3 & 10588.4 & 98.4 & 10590.46 & 98.4 \\
CP & 4 & 14.8 & 744 & 22.9 & 0.39 & 4.8 & 149.45 & 1.4 & 149.84 & 1.4 \\
WPP & 5 & 18.5 & 474 & 14.6 & 0.04 & 0.5 & 1.43 & $<0.01$ & 1.47 & $<0.01$ \\
DIP & 4 & 14.8 & 222 & 6.8 & 5.63 & 69.2 & 18.18 & 0.2 & 23.81 & 0.2 \\
VMW & 1 & 3.7 & 8 & 0.2 & 0.00 & 0 & 0.01 & $<0.01$ & 0.01 & $<0.01$ \\
& 27 & & 3247 & & 8.14 & & 10757.48 & & 10765.62 & \\
\hline
\end{tabular}

Table 5. Comparison of IPPS and RPIS results (tons/yr) for calculated wastewater pollution loads.

\begin{tabular}{l|cc|cc}
\hline \multirow{2}{*}{ Parameter } & \multicolumn{2}{|c|}{ BMISFMW } & \multicolumn{2}{c}{ DIP } \\
\cline { 2 - 5 } & IPPS & RPIS & IPPS & RPIS \\
\hline BOD & 0.89 & 0.00 & 1.90 & 92.24 \\
TSS & 10554.65 & 357.74 & 6.14 & 53.9 \\
Oil and grease & - & 60.39 & - & - \\
Nitrogen & - & - & - & - \\
Phosphate & - & 3.08 & - & - \\
Iron & - & 29.3 & - & - \\
Zinc & - & 1.079 & - & - \\
Chromium & - & 2.315 & - & - \\
\hline
\end{tabular}

wastewater pollution load was estimated at 10765.62 tons/yr, of which TSS and BOD represents 99.9 and $0.08 \%$ respectively. This relatively high TSS load in wastewater from the estate may impact negatively on the receiving surface water body by increase sedimentation on the water channel. The BMISFMW sector accounted for the highest TSS load of $98.4 \%$ with less than $1.63 \%$ coming from the other five sectors. The presence of fine particulates in wastewater arises from the various complex industrial processes of metals and steel products. The release of plasticizing agents, dyeing chemicals and resins from the CP sector may account for the about $1.39 \%$ TSS load from this sector. The nature of raw material, which are mainly organic in nature used by the DIP sector may account for high BOD in its wastewater representing $69.2 \%$ of the total load. The BMISFMW sector follows with $25.3 \%$ and CP with $4.79 \%$. The high number of industries and employee's strength of the BMISFMW sector reflects to an extent the high load of wastewater pollution from this sector. Comparatively, there was significant difference in the BOD and TSS loads estimated by IPPS and RPIS models (Table 5). RPIS accounted for the least TSS loads. The RPIS model accounts for oil, phosphate and $\mathrm{Cr}$ which are pollutants in surface water bodies. The annual tonnage of 60.39 ton/yr of oil, Cr load of 2.315 ton/yr may significantly alter the natural eco-system of the Ota industrial estate.

\section{Industrial toxic and toxic metal pollution load}

Industrial waste toxins can be broadly grouped into toxic chemicals and toxic metals. The toxic chemicals are synthetic organic compounds such as organochlorine compounds, organophosphates and complex inorganic compounds, while $\mathrm{Pb}, \mathrm{Cd}, \mathrm{Hg}, \mathrm{As}$, $\mathrm{Se}, \mathrm{Cr}, \mathrm{Bi}, \mathrm{Pt}, \mathrm{Ni}$ and many other metallic elements are the toxic metals prevalent in industrial waste. The persistence and bioaccumulative tendency of these substances, their metabolite and residues in the environment (air, land and water) endangers the environmental ecosystem and human health. Some or all of these toxic chemicals and toxic metal compounds are either used in primary production processes or as by-products from industrial processes. Table 6 shows the estimated total industrial toxic and toxic metal pollution (tons/yr) using the IPPS model. The toxic pollution load of the environmental media (air, land and water) was estimated at 1090.55tons/yr. The highest contributors were the BMISFMW, DIP and CP sectors with 47.3, 26.4 and $25.4 \%$ respectively. The distribution ratio of this toxic pollution load to air, land and water was 4:6:3. These toxic chemicals are often non-biodegradable; their accumulation in soils is more extensive than in air and water which explains the high load on land. Their presence in the atmosphere may be explained by 
Table 6. Estimated total industrial toxic and toxic metal pollution (tons/yr) using IPPS model.

\begin{tabular}{|c|c|c|c|c|c|c|c|c|c|c|}
\hline \multirow{2}{*}{ Sector code } & \multirow{2}{*}{ No. of industries } & \multirow{2}{*}{ No. of employee } & \multicolumn{4}{|c|}{ Toxic pollution } & \multicolumn{4}{|c|}{ Toxic metal pollution } \\
\hline & & & Air & Land & Water & Total & Air & Land & Water & Total \\
\hline FBT & 2 & 83 & 0.41 & 0.72 & 0.03 & 1.16 & 0.00 & 0.00 & 0.00 & 0.00 \\
\hline BMISFMW & 11 & 1716 & 114.35 & 380.01 & 21.01 & 515.37 & 9.66 & 1.55 & 1.55 & 12.76 \\
\hline $\mathrm{CP}$ & 4 & 744 & 132.29 & 141.13 & 3.10 & 276.52 & 0.35 & 0.15 & 0.15 & 0.65 \\
\hline WPP & 5 & 474 & 5.83 & 3.72 & 0.03 & 9.58 & 0.02 & 0.13 & 0.13 & 0.28 \\
\hline DIP & 4 & 222 & 151.2 & 125.4 & 11.06 & 287.66 & 0.03 & 6.53 & 0.14 & 6.70 \\
\hline VMW & 1 & 8 & 0.17 & 0.08 & 0.01 & 0.26 & 0.00 & 0.04 & 0.00 & 0.04 \\
\hline & 27 & 3247 & 404.25 & 651.06 & 35.24 & 1090.55 & 10.06 & 8.40 & 1.97 & 20.43 \\
\hline
\end{tabular}

volatilization of organic and inorganic compounds at high operational temperature during manufacturing process. Once emitted into the atmosphere, the pollutants get dispersed and travel great distances while some settles on land, vegetation and water bodies.

The total toxic metal pollution load was estimated at 20.43 tons/yr in the ratio of $5: 4: 1$ in air, land and water (Table 6). The highest contributor to this toxic metal pollution load was the BMISFMW sector, followed by DIP and $\mathrm{CP}$ with $62.5,32.8$ and $3.18 \%$ respectively. This trend is similar to that obtained for the estimated total toxic chemical pollution load. The atmosphere and soil (land) is the major sink for toxic metals. The BMISFMW sector releases the highest amounts of toxic metals through the gaseous emissions as observe for the total air pollution load in Table 2. Refining of Pig and Wrought Iron from the BMISFMW sector explains the high toxic pollution and toxic metal pollution load. High operational temperatures release large quantity of toxic chemical and metals into the atmosphere with sludge and slag which are by-product of this process on land. DIP sector was the second largest contributor of toxic chemical pollution and toxic metal pollution into the Ota industrial estate environment. This status was justified by the nature of raw materials used in plastic and rubber production. Raw material such as pigment, plastics, biocides are known to contain toxic chemicals and metals, while vanishes, lacquers, paint pigment, alkyd resins from the CP sector are equally responsible for the toxic organic chemical and metals in the environment. Toxic chemical pollutions were greater for BMISFMW, DIP and CP sectors than their corresponding toxic metal pollutions. The RPIS model estimates the solid waste load for the BMISFMW sector to be 10889.4tons/yr with hazardous solid waste having 9004.8tons/yr and hazardous sludge 1884.6tons/yr. This further establishes the fact that the refining of pig and wrought iron from the BMISFMW sector produces sludge which is hazardous by-product, and therefore, its disposal on land contributes toxic pollution and toxic metal pollution load to soil.

In summary, the environment shows evidence of likely pollution arising from industrial activities within the estate.
The BMISFMW sector is the major source of the environmental pollutants. There is need for further studies to evaluate the relationship between these modelled data and experimental data. This will further give great insight into the degree of environmental impacts of these industries.

\section{REFERENCES}

Beghin J, Roland-Holst DW, Van der Mensbrughe D (1995). Trade Liberalization and the Environment in the Pacific Basin: Coordinated Approaches to Mexican Trade and Environmental Policy. Afr. J. Agri. Econ., 77: 778-785.

Chou-Ping Y, Wu-Seng L, Jan-Tai K, Jih-Hung L (2010). Water Quality Modeling of a Hypoxic Stream. Pract. Period. Hazard. Toxic Radio. Waste Manage., 14(2): 115-123.

Economopoulos AP (1979). Rapid Assessment of Water and Air Pollution Sources in Abidjan, Ivory Coast. World Health Organization. Athens, pp. 1-56.

Ferrantino MJ, Linkins LA (1999). The Effects of Global Trade Liberalization on Toxic Emissions in Industry. Weltwirtschaftliches Archive. 135: 128-155.

Hettige M, Martin P, Singh M, Wheeler D (1995). The Industrial Pollution Projection System, Policy Research Department, Policy Research Working Paper 1431. World Bank.

Kenneth AR, Roland-Holst DW (2001). Industrial pollution linkages in North America: A linear analysis. Econo. Syst. Res., 13(2): 197-208.

Lee H, Roland-Holst D (1997). The Environment and Welfare Implications of Trade and Tax Policy. J. Develop. Econ., 52: 65-82.

Smith VK, Andrès JE (1996). Environmental and Trade Policies: Some Methodological Lessons. Environ. Develop Econ., 1(1): 19-40.

Strutt A, Kym A (2000). Will Trade Liberalization Harm the Environment? The Case of Indonesia to 2020. Environ. Res. Econ., 17(3): 203-232.

Tsigas M, Denise G, Thomas WH, Barry K (2001). Environmental Consequences of Trade Liberalization in the Western Hemisphere. In Mohan, M., Osvaldo, S. and Carlos, D. M. eds., The Sustainability of Long-Term Growth: Socioeconomic and Ecological Perspectives. Cheltenham, UK, Edward Elgar.

World Bank (1993). Latvia, The Transition to a Market Economy, World Bank, Washington, D.C

World Bank (1996). Viet Nam - Industrial Pollution Prevention (IPP) Sector Report, mimeo, Washington, D.C. 